\title{
ArcheoSciences
}

Revue d'archéométrie

\section{Gold leaf analysis of three baroque altarpieces from Porto}

Analyse de feuilles d'or de trois retables baroques de la ville de Porto

Ana Bidarra, João Coroado and Fernando Rocha

\section{(2) OpenEdition}

1 Journals

\section{Electronic version}

URL: https://journals.openedition.org/archeosciences/2552

DOI: 10.4000/archeosciences. 2552

ISBN: 978-2-7535-1598-7

ISSN: 2104-3728

Publisher

Presses universitaires de Rennes

\section{Printed version}

Date of publication: 31 December 2009

Number of pages: $417-421$

ISBN: 978-2-7535-1181-1

ISSN: 1960-1360

\section{Electronic reference}

Ana Bidarra, João Coroado and Fernando Rocha, "Gold leaf analysis of three baroque altarpieces from Porto", ArcheoSciences [Online], 33 | 2009, Online since 10 December 2012, connection on 01 February 2022. URL: http://journals.openedition.org/archeosciences/2552 ; DOI: https://doi.org/10.4000/ archeosciences.2552 


\title{
Gold leaf analysis of three baroque altarpieces from Porto
}

\author{
Analyse de feuilles d'or de trois retables baroques de la ville de Porto
}

Ana Bidarra*, João Coroado** and Fernando RochA*

\begin{abstract}
During the second half of the $17^{\text {th }}$ century and the first half of the $18^{\text {th }}$ century, Portugal experienced a rising altarpiece production and an increased taste for gold application in church decoration. Some examples of this tendency can be found in the northwest of Portugal, particularly in the baroque altarpiece productions of Porto, Braga, Vila Real and Viana do Castelo. Porto was the first area studied and three gilded wood-carved altarpieces from different churches were selected: São Bento da Vitória (SB), Santa Clara (SC) and São Francisco (SF). Qualitative and semi-quantitative analyses of the samples were performed by optical microscopy $(\mathrm{OM})$ of the cross-section using reflected and polarised light, and by scanning electron microscopy (SEM) in combination with energy dispersive spectroscopy (EDS). The main advantages and disadvantages of the use of SEM-EDS were discussed and the results regarding the presence of major and trace elements compared.

Résumé : Pendant la deuxième moitié du XVII siècle et la première moitié du XVIII siècle, au Portugal, est observée une production croissante de retables ainsi qu'une préférence pour l'application d'or dans la décoration des églises. Quelques exemples de cette tendance peuvent être observés dans le NordOuest du Portugal, en particulier dans le cas des retables produits à Porto, Braga, Vila Real et Viana do Castelo. Porto a été la première région étudiée et trois retables en bois doré provenant de différentes églises ont été sélectionnés : São Bento da Vitória (SB), Santa Clara (SC) et São Francisco (SF). Des analyses qualitatives et semi-quantitatives de prélèvements ont été réalisées par microscopie optique $(M O)$ de sections, en lumière réfléchie et polarisée, et par microscopie électronique à balayage (MEB) combinée à un système de spectroscopie en énergie dispersive (EDS). Les avantages et inconvénients de l'utilisation du MEB-EDS sont discutées et les résultats concernant la présence d'éléments majeurs et traces comparés.
\end{abstract}

Keywords: Gold leaf, baroque altarpieces, major and minor elements, SEM-EDS.

Mots-clés : feuille d'or, retables baroques, éléments majeurs, éléments traces, MEB-EDS.

\section{INTRODUCTION}

Baroque art was one of the most convincing ways used by the church to defend and impose its faith. It was an example of scenic art, where light, movement and sound have key roles, appealing to the senses (Ferreira-Alves, 1989). One of the most magnificent art forms took the shape of gilded wood-carved altarpieces covering partially or totally the interior of churches, in complex and structured architectures, working alone or in association with ceramic tiles (azulejos) or paintings. The craftsmen involved in the process were masters of this art. The carvers, sculptors, painters or gilders were well organised, and different workshops competed with each other to produce the best works.

* Departamento de Geociências and GeoBioTec Research Centre - Universidade de Aveiro, Campus Universitário de Santiago, PT, 3810-193 Aveiro, Portugal. (anabidarra@portugalmail.com), (frocha@geo.ua.pt)

** Departamento de Arte, Conservação e Restauro and GeoBioTec Research Centre - Instituto Politécnico de Tomar, Quinta do Contador, Estrada da Serra, PT, 2300-313 Tomar, Portugal. (jcoroado@ipt.pt) 
The city of Porto was one of the most important Portuguese production centres and had a great influence in the surrounding regions. According to Robert C. Smith's chronology, the Portuguese baroque wood working can be divided in two major periods: barroco nacional (c. 16801729) and barroco joanino (c. 1729-1750) (Smith, 1962). An example from the first period is the altarpiece from São Bento da Vitória, while examples of works from the second period are the Sáo Francisco and Santa Clara altarpieces.

Although there are several studies on Portuguese altarpieces from this period, addressing national or regional productions, these researches are focused on the typological, social, economic and religious aspects of these works. In terms of the study of the materials and techniques applied, the approach used to date is mainly based on the analysis of documents, such as treatises and orders from the manufacturing period, with references to the materials (wood, gold, pigments, varnishes) and to where and how they should be applied (Ferreira-Alves, 1989; 2004). However, there is a gap related to a direct study, focused exclusively on the gold leaf and its origin and characterisation.

The present work aims to provide a new approach to Portuguese baroque altarpieces, by focusing on the study of the gold leaf and its elemental analysis, and identifying a distinct fingerprint. This will be accomplished by the determination of the concentration of specific minor and trace elements, which should be characteristic of the metal and its provenance: platinum and palladium contents in South American gold ores (Colombian and Brazilian - Peruvian gold with lower contents); platinum contents in contemporary Eastern European gold; palladium, tin and antimony in other Latin American gold ores; and trace elements typical of telluride in gold from India after the $16^{\text {th }}$ century (Guerra and Calligaro, 2004). Due to the fact that most of the gold sources from the past are geo-chemically unknown, the accurate identification of the characteristic elements is a difficult task (Guerra, 2004). The evolution of gold processing is another obstacle, since the addition of other metals to improve the workability of the material, to reduce costs, or even to change colour, might contribute to the loss of information provided by trace elements.

\section{Methods}

The samples were selected from discrete but representative areas in the main altarpieces, such as the back of the columns or the steps of the throne. The collected samples came from high and hidden places, difficult to reach, where contamination should be at the minimum. For cross-sec- tion analysis, the samples were mounted in polyester resin (BYLAPOX $3085 \mathrm{~A}$ and B (2:1)) and were polished using a Struers Planopol-V device. The observation and photography of the samples (100x magnification) were obtained using optical microscopy (OM), with polarised and transmitted light (Zeiss Stemi, 2000-C), with an external artificial light system Zeiss KL 1500 LCD, image acquisition with digital camera AxioCam MRcS, and an Axio Vs 40 V4.4 Carl Zeiss Vision GmbH acquisition and treatment software. The mounting and observation of the samples followed the procedures applied to the analysis of easel paintings or polychrome sculptures (Khandekar, 2003). The study of the cross-sections allows determining the number, thickness, adhesion and cohesion of layers, the shape and size of the particles (Calvo, 2003), and the presence of more than one gilding; it also allows comparing the ground layer and the bole layer.

For the scanning electron microscopy (SEM), a Hitachi SU-70 equipped with a Bruker AXS energy dispersive spectrometer (EDS) with a Quantax 400 EDS system with liquid nitrogen free and XFlash Silicon Drift Detector (SDD) was used. The semi-quantitative results were based on a peak-to-background ZAF evaluation method (P/BZAF), ZAF representing a matrix correction, mainly based on analytical expressions for atomic number $(Z)$, dependent $\mathrm{X}$-ray yield, self-absorption (A), and secondary fluorescence enhancement $(\mathrm{F})$, provided by the Esprit software. A $15 \mathrm{KV}$ acceleration voltage and a current intensity of $32 \mathrm{~mA}$ were applied. The samples were coated with carbon. The use of SEM in combination with EDS increases sensitivity for lighter elements, and the spatial resolution for spot analysis is higher. Additionally, it allows the examination of the microstructure with line scans or two-dimensional mappings of element concentrations (Hein and Degrigny, 2008; Guerra, 2004). The mapping acquisition was carried out under the same conditions as the EDS spectrum, with no background elimination.

Two sets of samples were analysed in terms of the study of the cross-sections and the surface. In the first case, the study was focused on the bole and ground layers (elemental results not presented), and in the second case the study was focused on the gold and its physical and chemical aspects, such as homogeneity, abrasion, voids and elemental distribution. The areas were selected in terms of their homogeneity and lack of voids; a 300x400 $\mu \mathrm{m}$ area was scanned using a 300x magnification, and the elemental and semi-quantitative results were obtained after three measurements. The semi-quantitative results were normalised to $100 \%$. 


\section{Results}

The OM and SEM analyses revealed that the gold leaf from the SB, SC and SF altarpieces share important features, such as surface morphology, as well as extreme thinness and uniformity. The presence of ground and bole layers was visible, typical of traditional gilding (Martínez, 1997; SerckDewaide et al., 2004), with good adhesion and cohesion between them (Fig. 1). The analysis of SC samples raised several difficulties, due to the considerable presence of wax over the gold layer. The main differences were obtained in the EDS analysis; for the determination of the gold/silver/ copper alloy composition, the results were normalised to $100 \%$, revealing the use of a very pure gold (between 22 and $23 \mathrm{~K})$. The most significant differences were identified in the relative silver percentage, varying between $4.4 \%(\mathrm{SF})$ and $0.9 \%$ (SC) (Table 1).

The major elements were common to all samples (Fig. 2); aluminum and silicon were components of the bole layer, a clay layer rich in aluminum-silicates and iron. The results obtained from the study of minor elements should be carefully analysed, as due to the lower concentrations, the readings could lead to error. For instance, when studying Table 2 , the sample SB revealed the presence of platinum; however, the high concentration of gold and the proximity of $\mathrm{L}_{\alpha}{ }^{1}$ lines $(9.711 \mathrm{KeV}$ of $\mathrm{Au}$ and $9.441 \mathrm{KeV}$ of $\mathrm{Pt}$ ) and all other lines of both elements could be responsible for the overlap of the platinum peacks. The same thing happened when analysing SB silver and palladium $(2.984 \mathrm{KeV}$ and 2.838 $\mathrm{KeV}$, respectively, for $L \alpha^{1}$ lines), as both picks were practically overlapping. The same interpretation was given for the relatively high percentage of mercury in the SC sample: the mercury peaks were near the gold peaks $(9.987 \mathrm{KeV}$ and
$9.711 \mathrm{KeV}$, for $\mathrm{L} \alpha^{1}$ lines of $\mathrm{Hg}$ and $\mathrm{Au}$, respectively), and the automatic values were generated by the software deconvolution of the results (Goldstein, 1975).

By analysing the EDS data, it was possible to characterise the gold from SB as a $22 \mathrm{~K}$ gold and to identify the presence of palladium and tellurium; SC had the highest carat, almost 23, with the presence of palladium and titanium and SF samples is a $22 \mathrm{~K}$ gold with the presence of minor elements such as tin, tellurium and zinc. The mapping of the surface provided the topographic distribution of selected elements in a sample, with brighter areas where the element concentration is higher and faded areas for the lower concentrations. For SB samples, the gold, silver and copper distribution was clear (Fig. 3). When mapping SC for gold, silver and palladium, the distribution showed a clear distribution of gold and silver, and a palladium distribution with background interference.

\section{DisCUSSION AND CONCLUSION}

The major elements of gold alloys - gold, silver and copper - can be determined using the SEM-EDS technique. However, the interpretation of trace elements such as palladium, platinum, tellurium, tin, antimony or zinc raises several doubts concerning the certainty of their presence. This uncertainty is due not only to the very low concentration of these elements, but also to the interpretation of the spectrum peaks, where some elements such as platinum or tellurium have very close peaks to gold and calcium, making an accurate interpretation of the results very difficult. Other elements, such as ruthenium, rhodium, chromium or lead, were not detected. The presence of silicon, aluminum, iron,

Figure 1: SEM image $(2000 \mathrm{x})$. Crosssection of samples from SB (a), SC (b), and SF (c). 1 - Gold leaf; 2 - Bole layer; 3 - Ground layer.

Figure 1: Image $M E B$ (x2000). Section de prélèvements de $S B(a), S C(b)$, et $S F$ (c). 1-feuille d'or; 2 - bol; 3-souscouche

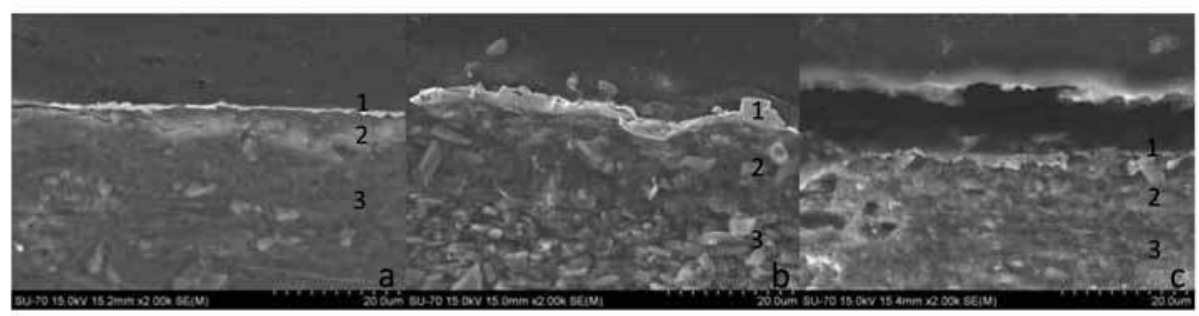

Table 1: Concentration of the alloy composition and gold carat in relative percentages (SB - São Bento; SC - Santa Clara; SF - São Francisco).

Tableau 1: Composition des alliages et teneurs en or en pourcentages relatifs (SB - São Bento; SC-Santa Clara; SF-São Francisco).

\begin{tabular}{|c|c|c|c|c|}
\hline Sample & $\mathrm{Au} \%$ & $\mathrm{Ag} \%$ & $\mathrm{Cu} \%$ & Carat \\
\hline SB & 91.99 & 2.9 & 5.11 & 22.08 \\
\hline SC & 94.91 & 0.91 & 4.18 & 22.78 \\
\hline SF & 91.65 & 4.41 & 3.94 & 22 \\
\hline
\end{tabular}




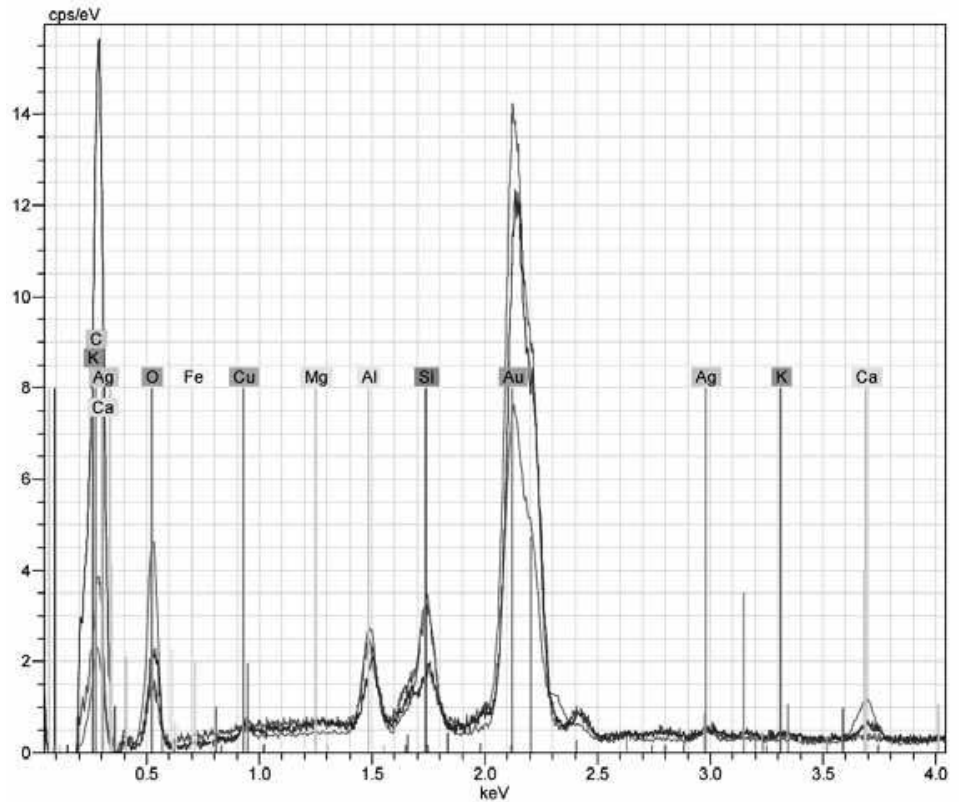

São Bento (SB) Santa Clara (SC) São Francisco (SF)
Figure 2: (See colour plate) EDS spectrum of major elements.

Figure 2: (Voir planche couleur) Spectre EDS des éléments majeurs

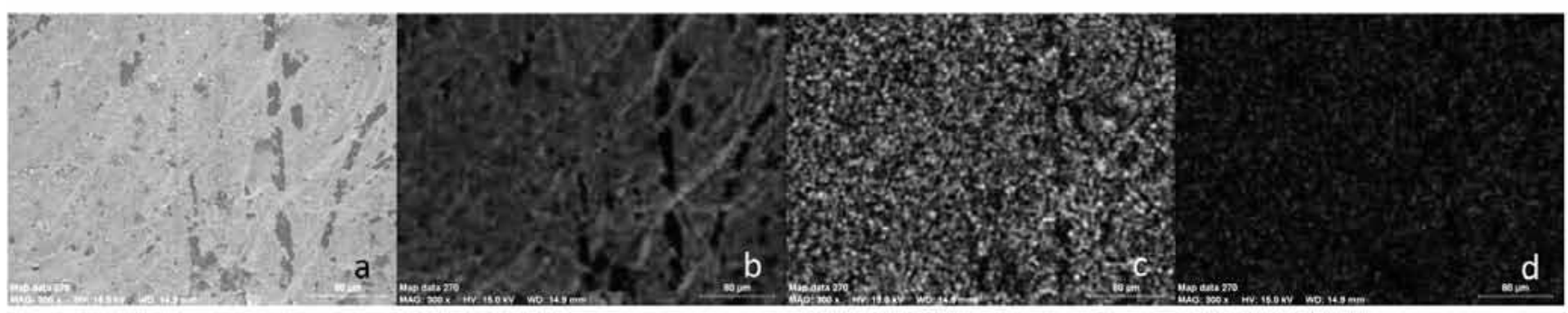

Figure 3: (See colour plate) São Bento (SB): SEM image (a) and EDS mapping of the surface - Au (b), Ag (c), and Cu (d) (300x). Figure 3: (Voir planche couleur) São Bento (SB): Image MEB (a) et cartographie EDS de la surface - Au (b), Ag (c) et Cu (d) (300x).

\begin{tabular}{|c|c|c|c|c|c|c|c|c|c|c|c|c|c|c|}
\hline Sample & Hg wt $\%$ & Error \% & $\mathrm{Pd} w \mathrm{wt} \%$ & Error \% & Pt wt $\%$ & Error \% & Sn wt $\%$ & Error \% & Te wt $\%$ & Error \% & Ti wt $\%$ & Error \% & Zn wt $\%$ & Error \% \\
\hline SB & nd & - & 0.96 & 0.6 & 4.96 & 0.9 & nd & - & 1.23 & 0.2 & nd & - & nd & - \\
\hline SC & 3.17 & 0.8 & 1.02 & 0.7 & nd & - & nd & - & nd & - & 1.31 & 0.1 & nd & - \\
\hline SF & nd & - & nd & - & nd & - & 2.91 & 0.6 & 1.45 & 0.2 & nd & - & 2.10 & 0.2 \\
\hline
\end{tabular}

Table 2: Weight percentage of minor elements - comparison between relative percentages (SB - São Bento; CS - Santa Clara; SF - São Francisco).

Tableau 2 : Concentrations en pourcent des éléments mineurs - comparaison entre les pourcentages relatifs (SB - Säo Bento; SC - Santa Clara; SF-São Francisco).

calcium and potassium were mainly contributions from the bole and ground layers. A spot analysis reduces the percentage of these elements, but not in a significant way. Since the results concerning the study of trace elements are not satisfactory, other procedures are now in order, such as inducti- vely coupled plasma mass spectrometry (ICP-MS) and the use of synchrotron radiation (SR).

Overall, this study is part of a larger project that aims to study the compositional characterisation of the gold leaf, the typification of its aging, and to establish provenance 
relations, allowing a better approach to the conservation and restoration of these coatings. Through this study, it will be possible to complement the information concerning the three selected altarpieces, and also to compare them with other altarpieces where the same masters have worked.

\section{Acknowledgements}

Portuguese Foundation for Science and Technology (FCT) for PhD grant FRH/BD/38593/2007.

GeoBioTec Research Centre - Aveiro.

Technological Centre of Ceramic and Glass (CTCV) Coimbra.

\section{References}

Calvo, A., 2003. Conservación y Restauración-Materiales técnicas y procedimientos - De la $A$ a la $Z$. Tercera edición. Barcelona, Ediciones del Serbal.

Ferreira-Alves, N.M., 1989. A Arte da Talha no Porto na Época Barroca. Artistas e clientela. Materiais e técnica. Vol.I e II. Porto, Arquivo Histórico, Câmara Municipal do Porto.

Ferreira-Alves, N.M., 2004. O douramento e a policromia no Norte de Portugal à luz da documentação dos séculos XVII e XVII. Policromia - A escultura policromada religiosa dos séculos XVII e XVIII. Estudo comparativo das técnicas, alteraçôes e conservação em Portugal, Espanha e Bélgica. Actas do Congresso Internacional, Lisboa 29, 30 e 31 de Outubro de 2002. Lisboa, Instituto Português de Conservação e Restauro, 17-22.

GoldsteIn, J.I., 1975. Electron beam - specimen interaction, in J.I. Goldstein and H. Yakowitz (eds.), Practical scanning elec- tron microscopy. Electron and ion microprobe analysis. New York, Plenum Press, 49-94.

Guerra, M.F., 2004. Fingerprinting ancient gold with proton beams of different energies, Nuclear Instruments and Methods in Physics Research Serie B 226: 185-198.

Guerra, M.F. and Calligaro, T., 2004. Gold traces to trace gold, Journal of Archaeological Science 31: 1199-1208.

Hein, A. and Degrigny, C., 2008. The application of nondestructive technologies for the damage assessment of metal objects, in V. Argyropoulos (ed.), Metals and Museums in the Mediterranean, Protecting, Preserving and Interpreting. Athens, The PROMET Consortium, 125-140.

KHANDEKaR, N., 2003. Preparation of cross sections from easel paintings, Reviews in Conservation 4: 52-64.

Martínez, E., 1997. Tratado del dorado, plateado y su policromia. Tecnología, conservación y restauración. Valencia, Departamento de Conservación y Restauración de Bienes Culturales, Universidad Politécnica Valência.

Serck-Dewaide, M., Rabelo, E., Sanyova, J., Ribeiro, I., Barreiro, A., Romáo, P., Le Gac, A., Naranjo, M.C., Gonzalez, M.J., Lopez, A.C., Arcaute, E.R., Ramos, R.G., Olano, M.B., Salvarredi, I.B., Ibarraran, E.M., 2004. Les techniques utilisées dans l'art baroque religioux des $\mathrm{XVII}^{\mathrm{e}}$ et $\mathrm{XVIII}^{\mathrm{e}}$ siècles au Portugal, en Espagne et en Belgique, in A.I. Seruya (ed.), Policromia - A escultura policromada religiosa dos séculos XVII e XVIII. Estudo comparativo das técnicas, alteraçóes e conservação em Portugal, Espanha e Bélgica. Actas do Congresso Internacional, Lisboa 29, 30 e 31 de Outubro de 2002. Lisboa, Instituto Português de Conservação e Restauro, 119-155.

Smith, R., 1962. A talha em Portugal. Lisboa, Livros Horizonte. 
